Г. О. Леженко, О. Є. Пашкова, О. М. Лебединець, І. В. Сидорова, Г. В. Крайня Запорізький державний медичний університет

\title{
ВПРОВАДЖЕННЯ ОНЛАЙН-НАВЧАННЯ ЯК ШЛЯХ УДОСКОНАЛЕННЯ САМОСТІЙНОЇ РОБОТИ СТУДЕНТІВ НА КАФЕДРІ ПЕДІАТРІї
}

\author{
G. O. Lezhenko, O. E. Pashkova, O. M. Lebedynets, I. V. Sidorova, H. V. Kraynya \\ Zaporizhzhia State Medical University \\ THE INITIATIVE OF ONLINE TRAINING AS THE WAY OF \\ IMPROVEMENT OF THE INDIVIDUAL WORK OF STUDENTS AT THE \\ PEDIATRICS DEPARTMENT
}

\begin{abstract}
Мета роботи - вивчення ефективності використання змішаної технології (технології “перевернутого класу”) для удосконалення навчання студентів медичного факультету на кафедрі педіатрії.

Основна частина. Проведено аналіз засвоєння матеріалу та довготривалого збереження знань при вивченні теми “Цукровий діабет у дітей” у 92 студентів медичного факультету в 2016-2017 роках. Студенти навчалися як за традиційною системою (45 студентів, перша група), так і з використанням змішаної технології навчання (технології “перевернутого класу”) (47 студентів, друга група). Проводилась оцінка вивчення теми у студентів 5 курсу у весняному семестрі та через 6 місяців у цих же студентів при продовженні навчання вже на 6 курсі в осінньому семестрі. Для оцінки якості засвоєння матеріалу використовували коефіцієнт засвоєння: задовільним засвоєння матеріалу вважалося при значенні коефіцієнта засвоєння 0,7, добрим - від 0,8 до 0,9 та відмінним - від 0,9 до 1,0 .

Згідно з отриманими даними, визначалося краще засвоєння теми студентами другої групи порівняно з групою студентів, які навчаються за традиційною методикою, за рахунок збільшення частки студентів, що освоїли матеріал на “добре” і “відмінно” як при первинному вивченні теми, так і після закінчення 6 місяців після вивчення теми.

Висновки. Таким чином, порівняльні дані оволодіння студентами матеріалів свідчать про підвищення якості підготовки при змішаному навчанні, за рахунок кращого збереження отриманих знань. Це дозволяє говорити про перевагу змішаної форми навчання з використанням технології “перевернутого класу”, при якій учні мають можливість опрацьовувати онлайн-матеріали різної спрямованості при підготовці до лекцій і практичних занять.
\end{abstract}

Ключові слова: онлайн-курси; змішане навчання; технологія “перевернутого класу”; вища медична освіта; педіатрія.

The aim of the work - to study the effectiveness of using the blended learning technology (flipped classroom technology) for improving the teaching of students of the medical faculty at the Department of Pediatrics.

The main body. The analysis of the material assimilation and the long-term preservation of knowledge in 92 students of the Faculty of Medicine from the study the theme of Diabetes Mellitus in Children in 2016-2017. Students were trained according to the traditional system (45 students - the group 1), and using the blended learning technology (flipped classroom technology) (47 students - the group 2). The satisfactory assimilation of the material at the value of the assimilation factor -0.7 , good - of 0.8 to 0.9 and excellent - of 0.9 to 1.0 was considered.

The students of the group 2 were better assimilated to the topic, compared to a group of students trained according to the traditional method, by increasing the proportion of students who mastered the material "good" and "excellent" both in the initial study of the topic and after 6 months after studying the topic, according to the data received.

Conclusions. Thus, the comparative data of students' mastery of materials indicate an improvement in the quality of training with mixed training, due to better preservation of the acquired knowledge. This allows us to speak about the advantage of the blended learning technology using the flipped classroom technology, in which students have the opportunity to work on online materials of different orientations in preparation for lectures and practical exercises.

Key words: online courses; blended learning technology; flipped classroom technology; higher medical education; pediatrics.

Вступ. Оволодіння професією лікаря вимагає навичок постійної самостійної роботи з інформаційними ресурсами та підвищення рівня знань у професійній сфері. Отримання медичної освіти

(ㄷ Г. О. Леженко, О. Є. Пашкова, О. М. Лебединець та ін. має бути не тільки першим кроком у професійній діяльності, а й кроком становлення навичок самовдосконалення та вміння користуватися сучасними освітніми технологіями. Одним із пріоритетних напрямків державної політики щодо розвитку ме- 
дичної освіти в Україні є впровадження інновацій та інформаційних технологій у навчальний процес і відповідність рівня медичної освіти світовим стандартам [1]. Медична реформа в Україні передбачає зміни в системі підготовки медичних кадрів із метою підвищення кваліфікації викладацького складу та якості освіти майбутніх лікарів. Тому навчальний процес у закладах вищої медичної освіти повинен бути орієнтований на використання сучасних інформаційних технологій [1, 3-5].

Серед нових технологій навчання з 2012 року у світі поширилися масові відкриті онлайн-курси комбінація безкоштовних відеолекцій, інтерактивних завдань та форумів для обговорення навчальних матеріалів. Вперше онлайн-курси були запропоновані в Стенфордському університеті (Stanford University) у США в 2011 році. В даний час різні онлайн-курси пропонують всі провідні університети світу [6]. Доступність онлайн-навчання дозволяє отримувати освіту в різних сферах діяльності, і як базової освіти, і додаткової освіти після завершення навчання в університеті.

Однак у медицині навчання тільки он-лайн неможливо, а вимагає практичного та клінічного досвіду, роботи безпосередньо в клініці з пацієнтами - змішаного навчання. До змішаного навчання належить форма навчання, при якій навчання проводиться як у традиційній очній формі, так і з використанням технологій дистанційного навчання. Раніше в медичних ВНЗ при підготовці лікарів використовувалася тільки класична очна форма навчання, яка передбачала наявність лекційного курсу та практичних занять. Проведення практичних занять вимагало від студента роботи з підручником та лекційним матеріалом для самостійної підготовки до заняття.

На сьогодні студент-медик у процесі навчання повинен опрацьовувати значно більшу кількість інформації. Одночасно 3 розвитком технологій інформація стала більш доступною. Відомо, що великий потік інформації з її доступністю призводить до зниження активності учня, i, як наслідок, до зниження якості освіти [7]. Це вимагає пошуку нових підходів у навчанні.

При підготовці фахівців медичного профілю пропонується використовувати змішане навчання - поєднання онлайн-навчання з традиційним викладанням. Було показано, що змішане навчання допомагає подолати розрив між теорією та практикою, а також підвищити якість підготовки студентів медичних спеціальностей $[8,9]$. Однією 3 інноваційних педагогічних технологій, яка може успішно використовуватися при навчанні у вищих медичних закладах, $є$ технологія “перевернутого класу”. Технологія “перевернутого класу” $€$ найвідомішою моделлю змішаного навчання, яка сприяє підвищенню рівня засвоєння матеріалу, що вивчається, та якості освіти [10-14].

Мета роботи - вивчення ефективності використання змішаної технології (технології “перевернутого класу”) для удосконалення навчання студентів медичного факультету на кафедрі педіатрії.

Основна частина. 3 метою вивчення ефективності використання технології “перевернутого класу” при навчанні студентів на кафедрі педіатрії був проведений аналіз засвоєння матеріалу та довготривалого збереження знань при вивченні теми “Цукровий діабет у дітей”.

Контроль якості засвоєння матеріалів теми та довготривалого збереження знань був проведений у 92 студентів 5 курсу медичного факультету в 2016-2017 роках. Проводилась оцінка оволодіння практичними навичками при роботі з пацієнтами в ендокринологічному відділенні Запорізької обласної клінічної дитячої лікарні, а також за результатами рішення ситуаційних та тестових завдань безпосередньо після вивчення теми у студентів 5-го курсу у весняному семестрі та через 6 місяців у цих же студентів при продовженні навчання вже на 6-му курсі в осінньому семестрі. Студенти навчалися як за традиційною системою (45 студентів, перша група), так і з використанням змішаної технології навчання (технології “перевернутого класу”) (47 студентів, друга група). У рамках навчальної програми студентам була прочитана лекція “Цукровий діабет у дітей”. Студенти першої групи при підготовці до занять використовували підручники та навчально-методичні матеріали. Студенти другої групи додатково до роботи з навчальною друкованою літературою використовували розміщені на сайті університету онлайн-матеріали для підготовки до лекції та заняття. Онлайн-матеріали для самостійної підготовки студентів включали в себе анотацію теми; глосарій; текстовий блок викладу матеріалу (конспект лекції) на тему “Цукровий діабет у дітей” із включеними наочно схемами, алгоритмами, таблицями та фотографіями, короткими відеолекціями та презентаціями за темою заняття; список рекомендованої обов'язкової та додаткової літератури; посилання на наявні ресурси в мережі “Інтернет” (у тому числі і різними мовами).

Для оцінки якості засвоєння матеріалу при роботі з тестами та ситуаційними завданнями використову- 
вали коефіцієнт засвоєння, що характеризує ступінь безпомилкової діяльності. Мінімальним значенням коефіцієнта засвоєння припускали показник $=0,7$, що свідчило про задовільне засвоєння матеріалу. Значення від 0,8, але нижче 0,9 відповідало доброму, від 0,9 до 1,0 - відмінному засвоєнню. У процентному співвідношенні задовільне засвоєння відповідало 70-79\% правильних відповідей, достатнє - 80-89\%, відмінне - від 90 \% та більше [15].

Тема “Цукровий діабет” вивчалася в рамках програми 5-го курсу з педіатрії. На 6-му курсі означена тема розглядалася в контексті диференційної діагностики, надання допомоги при невідкладних станах, особливостей терапії та диспансеризації при цукровому діабеті у дітей. Достатній рівень засвоєння матеріалів теми є актуальним у зв' язку 3 високим розповсюдженням цукрового діабету у світі в цілому та в Україні зокрема, зростанням числа хворих на цукровий діабет дітей. Від лікаря будьякого фаху в майбутньому буде потрібно як знання діагностичних критеріїв захворювання, так і принципів терапії цукрового діабету, а також діагностики і лікування гострих та хронічних ускладнень діабету, навичок надання невідкладної допомоги при ургентних станах пацієнтам із цією патологією. При аналізі засвоєння матеріалів студентами 5-го курсу при традиційній підготовці до занять на кафедрі педіатрії нами було виявлено нижчу якість оволодіння матеріалами, призначеними для самостійного вивчення [16]. Це може свідчити про недостатність самоконтролю, навичок організації самостійної роботи, а також у подальшому це може впливати на якість медичної освіти в цілому та на професійний рівень лікаря в майбутньому.

Так, при проведенні аналізу засвоєння теми “Цукровий діабет у дітей” студентами 5 курсу медичного факультету за результатами оволодіння практичними навичками роботи з пацієнтами, рішення ситуаційних завдань та тестових питань безпосередньо після вивчення теми задовільне засвоєння матеріалу (значення коефіцієнта засвоєння 0,70-0,79) визначалося у 23 (51 \%) студентів першої групи та у 18 (38,3 \%) студентів другої групи; добре засвоєння (значення коефіцієнта 0,80-0,89) у 19 (42,2 \%) та 25 (53,2 \%) відповідно; відмінне засвоєння (значення коефіцієнта 0,90 та більше) у 2 (4,4 \%) та 5 (10,6 \%) студентів відповідно. У другій групі було достовірно менше студентів із задовільними знаннями та одночасно достовірно більше з добрим рівнем знань. Частка студентів, що показали відмінний результат у навчанні, в другій групі була трохи вищою, ніж у першій групі, проте без достовірних відмінностей.

Таким чином, визначалося краще засвоєння теми студентами, які навчалися з використанням онлайнматеріалів при підготовці до заняття, за рахунок збільшення частки студентів, що освоїли матеріал на “добре” та “відмінно” (32-68,1 \% студентів другої групи проти 45-55 \% першої групи) при новій формі підготовки. Слід зазначити, що в процесі проведення практичного заняття в групі змішаного навчання, завдяки попередній самостійній підготовці студентів, викладач більше приділяв увагу практичній частині заняття, роботі з пацієнтами, що дозволило студентам більш глибоко оволодіти навчальним матеріалом.

При проведенні аналізу збереження знань по темі “Цукровий діабет у дітей” через 6 місяців у тих же студентів, що навчаються вже на 6 курсі медичного факультету, за тими ж критеріями (результатами оволодіння практичними навичками роботи з пацієнтами, рішення ситуаційних завдань та тестових питань) при оцінці вхідного рівня знань на занятті задовільне засвоєння матеріалу (значення коефіцієнта засвоєння 0,70-0,79) визначалося у 23 (51 \%) студентів першої групи та у 18 (38,3 \%) студентів другої групи; добре засвоєння (значення коефіцієнта 0,80-0,89) - у 19 (42,2 \%) та 25 (53,2 \%) відповідно; відмінне засвоєння (значення коефіцієнта 0,90 та більше) - у 2 (4,4 \%) та 5 (10,6 \%) студентів відповідно.

Згідно з отриманими результатами, після закінчення 6 місяців після вивчення теми “Цукровий діабет у дітей” студентами 6 курсу медичного факультету були показані більш низькі показники доброго засвоєння матеріалу за рахунок підвищення частки студентів із задовільним рівнем знань в обох групах. Однак у першій групі студентів, які навчалися за класичною схемою, це зниження було більш вираженим, ніж у студентів, які навчалися за змішаною технологією. На нашу думку, це можна пояснити більш активною участю студентів у процесі навчання при використанні онлайн-матеріалів та технології “перевернутого класу”. Відомо, що активна участь учня підвищує показники засвоєння матеріалів у ВНЗ медичного профілю [8, 10].

Перехід до моделі “перевернутого класу” є переходом від більш активної позиції викладача до більшої активності учня. Модель “перевернутого класу” вперше запропонували в 2007 році два вчителі - Джонатан Бергман (Jonathan Bergman) та Аарон Семс (Aaron Sams), які мали на меті поліпшити на- 
вчання учнів, які часто пропускають заняття. Потім ця ідея оформилася в новий освітній напрям [9, 12].

Модель “перевернутий клас” як варіант змішаної моделі навчання дозволяє більш ефективно працювати під час практичної частини з викладачем, оскільки при підготовці до заняття студентам запропоновано самостійно розібратися з основами теми за допомогою онлайн-матеріалів. Це дозволяє на занятті скоротити час розбору нового теоретичного матеріалу, присвятивши його обговорення найбільш складним питанням. Велика частина часу заняття відводиться на практичне застосування знань у ході вирішення ситуаційних завдань та на безпосередню роботу у клініці біля ліжка пацієнта. Така модель сприяє підвищенню мотивації навчання у студентів з різним рівнем засвоєння матеріалу.

При аналізі якості засвоєння частка студентів, що відмінно оволоділи матеріалом, у другій групі була трохи вищою, ніж у першій групі, відразу після вивчення теми та через 6 місяців за даними довготривалого збереження знань, але без достовірних відмінностей. На нашу думку, це пояснюється спочатку більш високою мотивацією, умінням організувати самостійну роботу студентів, які стабільно демонструють високі показники при навчанні у медичному ВНЗ.

При організації навчального процесу у медичному університеті необхідно враховувати, що у різних студентів можуть спочатку переважати різні шляхи сприйняття інформації - візуальний, аудіальний, кінестетичний [17]. Та, незважаючи на це, в процесі навчання в університеті створюються умови для розвитку всіх шляхів отримання інформації, у студентів 5 курсу зберігається переважний канал оволодіння матеріалом. У подальшому в лікарській діяльності потрібен достатній розвиток всіх шляхів сприйняття, чому методика “перевернутого класу” сприяє більшою мірою, ніж класична схема навчання.

На відміну від класичної підготовки до заняття з використанням лекційного курсу та підручника, онлайн-матеріал сприяє надходженню інформації по різних каналах сприйняття. Крім того, грамотно підготовлений онлайн-курс дозволяє студенту краще орієнтуватися в необхідній та другорядній інформації, виділяти найбільш важливі проблеми досліджуваної теми. Це сприяє формуванню клінічного мислення, вміння проведення диференційної діагностики.

На завершення самостійного вивчення матеріалу має бути запропоновано вирішення ситуаційних завдань та тестування з вивченої теми. Ситуаційні завдання та тести повинні бути складені таким чи- ном, щоб виявити можливі прогалини в засвоєнні матеріалу та стимулювати повторно самостійно опрацювати тему за допомогою онлайн-матеріалів. Одночасно виявлені складнощі засвоєння матеріалу сприяють більш ефективному обговоренню при проведенні практичного заняття з викладачем.

Необхідно відзначити, що використання онлайнматеріалів та змішані технології навчання підвищують якість засвоєння матеріалів студентами і через більш високі вимоги до педагога та виключення використання у процесі навчання застарілих навчальних матеріалів. Підготовка онлайн-матеріалів, посилання на сучасну літературу та ресурси Інтернет-простору вимагають від викладача підвищення кваліфікації, постійного самонавчання одночасно 3 розвитком знань у конкретній галузі. Одночасно у викладача звільняється більше часу на практичному занятті для розбору клінічних ситуаційних завдань та роботи з пацієнтами, концентрації на розвитку практичних навичок та умінь студентів. Це також вимагає більш високого професіоналізму викладача й одночасно сприяє підтримці цього високого рівня.

Таким чином, порівняльні дані оволодіння студентами 5 курсу медичного факультету матеріалами по темі “Цукровий діабет у дітей” дозволяють говорити про перевагу змішаної форми навчання, технології “перевернутого класу”, коли учні мають можливість опрацьовувати онлайн-матеріали різної спрямованості при підготовці до лекцій та практичних занять. Змішана форма навчання підвищує ефективність навчання, що особливо чітко виявляється щодо збереження отриманих знань через 6 місяців після завершення вивчення теми.

Висновки. 1. Змішана технологія (технологія “перевернутого класу”) може успішно використовуватися при навчанні студентів 5 курсу медичного факультету на кафедрі педіатрії.

2. Якість засвоєння матеріалу по темі вище при використанні змішаної технології (технології “перевернутого класу”) при навчанні студентів, що особливо чітко виявляється щодо збереження отриманих знань через 6 місяців після завершення вивчення теми. Це свідчить про ефективність використання змішаної технології (технології “перевернутого класу”) при навчанні студентів медичного факультету на кафедрі педіатрії.

3. Запровадження змішаної технології (технології “перевернутого класу”) при навчанні студентів медичного факультету на кафедрі педіатрії знижує ризики неякісної освіти, підвищує вимоги до педагога, робить необхідним постійне оновлення та вдосконалення матеріалів для онлайн-підготовки студентів. 


\section{Список літератури}

1. Шляхи реформування системи вищої медичної освіти в Україні в сучасних умовах / О. В. Лінчевський, В. М. Черненко, Ю. С. П’ятницький, І. Є. Булах // Сучасні підходи до вищої медичної освіти в Україні (з дистанційним під’єднанням ВМ(Ф)НЗ України за допомогою відеоконференц-зв’язку) : матеріали XIV Всеукр. наук.практ. конф. 3 міжнар. участю, присвяченої 60-річчю ТДМУ. - Тернопіль, 2017. - Т. 1. - С. 3-5.

2. Проблеми та перспективи вищої медичної освіти у реалізації Національної стратегії реформування системи охорони здоров'я України / В. М. Мороз, Ю. Й. Гумінський, Л. В. Фоміна, Т. Л. Полеся // Проблеми та перспективи вищої медичної школи у розробці та реалізації Національної стратегії побудови нової системи охорони здоров’я в Україні на період 2015-2025 рр. : матеріали навч.-метод. конф. - Вінниця, 2015. - С. 3-6.

3. Мельник I. В. Навчально-методичне забезпечення підготовки студентів у вищих навчальних закладах МO3 України: стан та першочергові завдання / I. В. Мельник, М. О. Поліщук // Сучасні підходи до вищої медичної освіти в Україні (з дистанційним під’єднанням ВМ(Ф) НЗ України за допомогою відеоконференц-зв'язку) : матеріали XIV Всеукр. наук.-практ. конф. з міжнар. участю, присвяченої 60-річчю ТДМУ. - Тернопіль, 2017. T. 1. - C. 11-14.

4. Організація навчального процесу у вищих навчальних закладах Міністерства охорони здоров’я України в умовах впровадження Закону України “Про вищу освіту” (за підсумками моніторингу в 2016 р.) / Ю. С. П’ятницький, І. В. Мельник, М. О. Поліщук, Ю. І. Фисун // Актуальні питання якості медичної освіти : матеріали XIII Всеукр. наук.-практ. конф. з міжнар. участю. - Тернопіль, 2016. - С. 22-26.

5. Деякі питання імплементації Закону України “Про вищу освіту” у діяльність вищих навчальних закладів / Ю. М. Колесник, Ю. М. Нерянов, В. А. Візір [та ін.] // Реалізація Закону України “Про вищу освіту” у вищій медичній та фармацевтичній освіті України : матеріали Всеукр. навч.-наук. конф. з міжнар. участю, 21-22 травня 2015 р., Тернопіль. - Тернопіль, 2015. - С. 57.

6. Liyanagunawardena T. R. MOOCs: A Systematic Study of the Published Literature 2008-2012 / T. R. Liyanagunawardena, A. A. Adams, S. A. Williams // The International Review of Research in Open and Distance Learning. 2013. - Vol. 14, No. 3. - P. 202-227.

\section{References}

1. Linchevskyi, O.V., Chernenko, V.M., Piatnytskyi, Yu.S., \& Bulakh, I.Ye. (2017). Shliakhy reformuvannia systemy vyshchoi medychnoi osvity v Ukraini v suchasnykh umovakh [The ways of higher medical education system reforming in Ukraine in the modern context]. XIV Vseukrainskoi naukovo-praktychnoi konferentsii z
7. Современные образовательные технологии: педагогика и психология : монография. Книга 16 / [О. К. Асекретов, Б. А. Борисов, Н. Ю. Бугакова и др.]. - Новосибирск : Издательство ЦРНС, 2015. - 318 с.

8. The role of blended learning in the clinical education of healthcare students: a systematic review / M. Rowe, J. Frantz, V. Bozalek // Med. Teach. - 2012. - Vol. 34 (4). P. 216-221.

9. Augustin M. How to learn effectively in medical school: test yourself, learn actively, and repeat in intervals / M. Augustin // Yale J. Biol. Med. - 2014. - Vol. 87 (2). P. 207-212.

10. Results of a flipped classroom teaching approach in anesthesiology residents / S. M. Martinelli, F. Chen, A. N. DiLorenzo [et al.] // J. Grad. Med. Educ. - 2017. Vol. 9 (4). - P. 485-490.

11. Does the flipped classroom improve learning in graduate medical education? / J. Riddell, P. Jhun, C. C. Fung [et al.] // J. Grad. Med. Educ. - 2017. - Vol. 9 (4). - P. 491-496.

12. Wakabayashi N. Flipped classroom as a strategy to enhance active learning / N. Wakabayashi // Kokubyo Gakkai Zasshi. - 2015. - Vol. 81 (3). - P. 82 (1). - P. 1-7.

13. Friend or foe. Flipped classroom for undergraduate electrocardiogram learning: a randomized controlled study / Z. Rui, X. Lian-Rui, Y. Rong-Zheng [et al.] // BMC Med. Educ. - 2017. - Vol. 17 (1). - P. 53.

14. Martínez-Caro E. An application of the performanceevaluation model for e-learning quality in higher education / E. Martínez-Caro, J.-G. Cegarra-Navarro, J. G. CepedaCarrión // Total Quality Management \& Business Excellence. - 2015. - No. 5-6 (26). - Р. 632-647.

15. Булах I. Є. Проблеми оцінювання знань студентів у контексті вимог Болонської декларації / I. Є. Булах, О. П. Волосовець, М. Р. Мруга // Медична освіта. -2011. № 2. - С. 2-22.

16. Оцінка якості засвоєння студентами 5 курсу медичного факультету матеріалу для самостійної підготовки на кафедрі госпітальної педіатрії / Г. О. Леженко, Ю. Г. Резніченко, О. Є. Пашкова [та ін.] // Вища медична освіта: сучасні виклики та перспективи : зб. наук. праць наук.практ. конф. $з$ міжнар. участю. - К., 2016. - С. 135-138.

17. Фролова Е. В. Анализ стилевых особенностей восприятия: психолого-педагогические аспекты / Е. В. Фролова // Вісник Харківського національного університету імені В. Н. Каразіна. Серія “Психологія”. 2010. - № 913, вип. 44. - С. 166-170.

mizhnarodnoiu uchastiu, prysviachenoi 60-richchiu TDMU "Suchasni pidkhody do vyshchoi medychnoi osvity $v$ Ukraini (z dystantsiinym pidiednanniam VM(F)NZ Ukrainy za dopomohoiu videokonferents-zviazku)" - Materials of the XIV All-Ukrainian Scientific-Practical Conference on International Participation devoted to the 60th anniversary 
of the State Duma "State-of-the-art approaches to higher medical education in Ukraine (with the remote connection of $V M(F)$ NZ of Ukraine with the help of videoconferencing)”, Ternopil [in Ukrainian].

2. Moroz, V.M., Huminskyi, Yu.Y., Fomina, L.V., \& Polesia, T.L. (2015). Problemy ta perspektyvy vyshchoi medychnoi osvity u realizatsii Natsionalnoi stratehii reformuvannia systemy okhorony zdorovia Ukrainy [Problems and prospects of higher medical education in the implementation of the National Strategy for Health Reform in Ukraine]. Navchalno-metodychna konferentsiia "Problemy ta perspektyvy vyshchoi medychnoi shkoly u rozrobtsi ta realizatsii Natsionalnoi stratehii pobudovy novoi systemy okhorony zdorovia $v$ Ukraini na period 2015-2025 rr" - Materials of Teaching Method. Conference "Problems and Prospects of the Higher Medical School in the Development and Implementation of the National Strategy for the Construction of a New Health Care System in Ukraine for the Period 2015-2025”, Vinnytsia [in Ukrainian].

3. Melnyk, I.V., \& Polishchuk, M.O. (2017). Navchalno-metodychne zabezpechennia pidhotovky studentiv u vyshchykh navchalnykh zakladakh MOZ Ukrainy: stan ta pershocherhovi zavdannia [Educational and methodological provision of students' training in higher educational establishments of the Ministry of Health of Ukraine: state and priority tasks]. Materialy XIV Vseukrainskoi naukovo-praktychnoi konferentsii z mizhnarodnoiu uchastiu, prysvyachenoi 60-richchiu TDMU "Suchasni pidkhody do vyshchoi medychnoi osvity $v$ Ukraini (z dystantsiinym pidiednanniam $V M(F) N Z$ Ukrainy za dopomohoiu videokonferents-zviazku)" - Materials of the XIV All-Ukrainian Scientific and Practical Conference with International Participation devoted to the 60th anniversary of the State Duma of Ukraine "Modern Approaches to Higher Medical Education in Ukraine (with VM $(F)$ Remote Connection of the National University of Ukraine by means of videoconferencing)", Ternopil, pp. 11-14 [in Ukrainian].

4. Piatnytskyi, Yu.S., Melnyk, I.V., Polishchuk, M.O., \& Fysun, Yu.I. (2016). Orhanizatsiia navchalnoho protsesu u vyshchykh navchalnykh zakladakh Ministerstva okhorony zdorovia Ukrainy v umovakh vprovadzhennia Zakonu Ukrainy "Pro vyshchu osvitu” (za pidsumkamy monitorynhu v 2016 r.) [Learning process organization at higher educational institutions of Ministry of Healthcare of Ukraine under the conditions of Higher Education Act of Ukraine introduction]. Aktualni pytannia yakosti medychnoi osvity: materialy XIII Vseukr. nauk.-prakt. konf. z mizhnar. uchastiu Current Issues of Medical Education Quality: Proceedings of XIII All-Ukrainian Scientific and Practical Conference with International Participation. Ternopil, pp. 22-26 [in Ukrainian].

5. Kolesnyk, Yu.M., Neruianov, Yu.M., Vizir, V.A., Tumanskyi, V.O., Avramenko, M.O., \& Krut, Yu.Ya. (2015). Deiaki pytannia implementatsii Zakonu Ukrainy
"Pro vyshchu osvitu” u diialnist vyshchykh navchalnykh zakladiv [Some issues of the implementation of the Law of Ukraine "On Higher Education" in the activities of higher educational institutions]. Materialy Vseukrainskoi navchalnonaukovoi konferentsii z mizhnarodnoiu uchastiu "Realizatsiia Zakonu Ukrainy "Pro vyshchu osvitu" u vyshchii medychnii ta farmatsevtychnii osviti Ukrainy" - Materials of the All-Ukrainian Educational and Scientific Conference with International Participation "Implementation of the Law of Ukraine" On Higher Education "in the Higher Medical and Pharmaceutical Education of Ukraine”, Ternopil, p. 57 [in Ukrainian].

6. Liyanagunawardena, T.R., Adams, A.A., \& Williams, S.A. (2013). [MOOCs: A Systematic Study of the Published Literature 2008-2012]. The International Review of Research in Open and Distance Learning, 3, 202-227.

7. Asekretov, O.K., Borisov, B.A., \& Buhakova, N.Yu. (2015). Sovremennye obrazovatelnye tekhnologii: pedagogika i psikhologiya [Modern educational technologies: pedagogy and psychology]. Novosibirsk: Izdatelstvo TsRNS [in Russian].

8. Rowe, M., Frantz, J., \& Bozalek, V. (2012). The role of blended learning in the clinical education of healthcare students: a systematic review. Med. Teach., 34 (4), 216-221.

9. Augustin, M. (2014). How to learn effectively in medical school: test yourself, learn actively, and repeat in intervals. Yale J. Biol. Med., 87(2), 207-212.

10. Martinelli, S.M., Chen, F., DiLorenzo, A.N., Mayer, D.C., \& Fairbanks, S. (2017). Results of a flipped classroom teaching approach in anesthesiology residents. J. Grad. Med. Educ., 9(4), 485-490.

11. Riddell, J., Jhun, P., Fung, C.C., Comes, J., Sawtelle, S., Tabatabai, R., Joseph, D. et al. (2017). Does the flipped classroom improve learning in graduate medical education? J. Grad. Med. Educ., 9 (4), 491-496.

12. Wakabayashi, N. (2015). Flipped classroom as a strategy to enhance active learning. Kokubyo Gakkai Zasshi, 81(3)-82(1), 1-7.

13. Rui, Z., Lian-Rui, X., Rong-Zheng, Y., Jing, Z., XueHong, W., \& Chuan, Z. (2017). Friend or foe? Flipped classroom for undergraduate electrocardiogram learning: a randomized controlled study. BMC Med Educ., 17(1), 53.

14. Martínez-Caro, E., Cegarra-Navarro, J.G., \& CepedaCarrión, J.G. (2015). An application of the performanceevaluation model for e-learning quality in higher education. Total Quality Management \& Business Excellence, 5-6 (26), 632-647.

15. Bulakh, I.Ye., Volosovets, O.P., \& Mruha, M.R. (2011). Problemy otsiniuvannia znan studentiv u konteksti vymoh Bolonskoi deklaratsii [Problems of assessment of students' knowledge in the context of the requirements of the Bologna Declaration]. Medychna osvita - Medical Education, 2, 2-22 [in Ukrainian].

16. Lezhenko, H.O., Reznichenko, Yu.H., Pashkova, O.Ye., Hyria, O.M., Lebedynets, O.M., \& Kamenshchyk, A.V. 
(2016). Otsinka yakosti zasvoiennia studentamy 5 kursu medychnoho fakultetu materialu dlia samostiinoi pidhotovky na kafedri hospitalnoi pediatrii [Assessment of the quality of students' acquisition of the 5th year of the medical faculty of material for self-training at the Department of Hospital Pediatrics]. Zbirnyk naukovykh prats'naukovo-praktychnoi konferentsii z mizhnarodnoiu uchastiu "Vyshcha medychna osvita: suchasni vyklyky ta perspektyvy" Collection of scientific works of scientific and practical conference with international participation "Higher medical education: modern challenges and perspectives”, Kyiv [in Ukrainian]. 17. Frolova, E.V. (2010). Analiz stilevykh osobennostey vospriyatiya: psikhologo-pedagogicheskie aspekty [Analysis of style features of perception: psychological and pedagogical aspects]. Visnyk Kharkivskoho natsionalnoho universytetu imeni V.N. Karazina. Seria: Psykholohiia-Bulletin of Kharkiv National University named after V.N. Karazin. Series: Psychology, 913 (44), 419-425 [in Russian].

Отримано 30.03.18

Електронна адреса для листування: krayniy0707@gmail.com 